\title{
Automatic Measurement of Shoreline Change on Djerba Island of Tunisia
}

\author{
Maged Bouchahma ${ }^{1} \&$ Wanglin Yan ${ }^{1}$ \\ ${ }^{1}$ Yan Lab, Graduate school of media and governance, SFC Keio University, Fujisawa-shi, kanagawa-ken, Japan \\ Correspondence: Maged Bouchahma, Yan Lab, Graduate school of media and governance, SFC Keio University, \\ 5322 Endo, Fujisawa-shi, kanagawa-ken, Japan. Tel: 81-466-49-3623. E-mail: boumaged@sfc.keio.ac.jp
}

Received: May 31, 2012 Accepted: June 23, 2012 Online Published: July 4, 2012

doi:10.5539/cis.v5n5p17 URL: http://dx.doi.org/10.5539/cis.v5n5p17

\begin{abstract}
This study presents measurement of changes using image processing techniques, Digital Shoreline Analysis System (DSAS) and Landsat images along the coast of the island of Djerba, Tunisia. Three regions of this island were selected: Rass Errmall, El Kastil and Aghir. Accretions as well as erosion processes were observed in the study areas between 1984 and 2009. The average of the erosion was around $-6.95 \mathrm{~m} / \mathrm{yr}$ in Aghir. The average of erosion is around $-4.09 \mathrm{~m} / \mathrm{yr}$ and accretion trend is around $+11.7 \mathrm{~m} / \mathrm{yr}$ in Rass Errmall. El kestil was under a remarkable accretion with $21.14 \mathrm{~m} / \mathrm{yr}$ during the same period.
\end{abstract}

Keywords: shoreline change, DSAS, Djerba, Landsat TM, Geographic Information System (GIS)

\section{Introduction}

Coastal zones are exposed to a series of dynamic nature processes that usually causes changes in long and short time spans. Examples of these processes include coastal erosion, sediment transport, environmental pollution, and coastal development. The impacts of these coastal changes include loss of life and property, security of harbors, change of the coastal socio-economic environment, and decrease of coastal land resources. Extraction of shorelines to monitor coastal zones for national development and environmental protection is an important task (Rasuly, Naghdifar, \& Rasoli, 2010). IGDC (International Geographic Data Committee) consider shoreline as one of the 27 most important geographic features on the earth's surface (Li, Di, \& Ma, 2001). An idealized definition of shoreline is that it coincides with the physical interface of land and water (Li, Di, \& Ma, 2001). The analysis of shoreline change and erosion cause utilizing information about natural processes, such as shoreline erosion, shoreline accretion, and slope of coastal zone. Monitoring of shoreline change needs a long-term commitment and is based on the temporal change modeling using a GIS database. Objective decisions on shoreline change are usually made based on shoreline and erosion monitoring data that are usually acquired cumulatively over a long period of time (Ali \& Li, 2000; Li, Liu, \& Felus, 2001a; Li, Ma, Di, \& Ali, 2001b). (Mills, Buckley, Mitchell, Clarke, \& Edwards, 2005) consider shoreline change as one of the most dynamic processes in coastal area. Among the commonly used shoreline change prediction models, the one-line model has been used successfully in various studies to calculate shoreline changes (U.S. Army Corps. of Engineers, 1992; $\mathrm{Li}, \mathrm{Ma}, \mathrm{Di}, \& \mathrm{Ali}, 2001 \mathrm{~b}$ ). This model has been employed intensively over the years to compute the long-term shoreline change and have been extended to deal with the cross-shore sediment transport as well. This model is based on the assumption that the geometric shape of the shoreline does not change and that the change occurs only at right angles to the shoreline. This implies that the sediment transport is uniformly distributed over the moving portion of the shoreline profile. The quantification and analysis of shoreline changes require not only the consideration of both spatial and temporal attributes, but also their integration into GIS database. This is because GIS is an important digital mapping and analysis tool in coastal areas needed to store, retrieve, manipulate and analyze coastal data. However, most commercial GIS's are fully capable of handling the unique coastal data. This deficiency narrows the utilization of GIS for coastal mapping purposes where the system's dynamics need to be represented. Accordingly efficient methods are needed to handle the spatio-temporal data of coastal applications within a GIS environment. (Thieler, Himmelstoss, Zichichi, \& Miller, 2005) developed an extension for ArcGIS allowing an automatic measurement of the shoreline changes. Many researches utilized remote sensing data to analyse coastal environments. Satellite images and GIS are used to map and analyse wetland (Maiti \& Bhattacharya, 2009; Rebelo, Finlayson, \& Nagabhatla, 2009). Landsat TM and ETM+ data are used in 
order to monitor land in coastal areas (Ghanavati, Firouzabadi, Jangi, \& Khosravi, 2008; Ding, Wang, Wu, Zhou, Shi, \& Ding, 2007; Kuleli, Guneroglu, Karsli, \& Dihkan, 2011).

In this research, regions under important changes (Bouchahma, Wanglin, \& Ouessar, 2012) around the island of Djerba as one of the island of Mediterranean sea were investigated in point of coastline changes. Erosion, deposition, sedimentation and human uses of dunes, mining and construction dams have caused the morphological changes (accretion or erosion) of coastal area along some regions of the island. Analysis and measurement of shoreline changes with the use of image processing methods, DSAS software and remote sensing data have been done.

\section{Study Area and Material}

As an internationally renowned tourist destination, Djerba is an island $\left(514 \mathrm{~km}^{2}\right)$ southeast Tunisian belongs to the Gulf of Gabes $\left(33^{\circ} 47^{\prime} 0^{\prime \prime} \mathrm{N}, 10^{\circ} 53^{\prime} 0^{\prime \prime} \mathrm{E}\right.$ - WGS 84 coordinates) (Figure 1). It is separated from the mainland by $2.5 \mathrm{~km}$. Since the early 1970s, the island of Djerba, and especially its coast, has undergone profound socio-economic changes; cause of environmental degradation Djerba has a very low average altitude $(20 \mathrm{~m})$ and a simple geological stratum. The tidal wave hotel has been done in three stages, with a pioneer phase from 1953, an increase in accommodation in the years 1960-1970, followed by a long period of stagnation and then a spectacular hotel boom since 1990. The socio-economic mutation that Djerba has experienced recently has a negative impact on the natural environment, since they affected the intensity of old reports between man and his environment. Manifestations of degradation are many and varied. They hit the beaches, water resources and landscapes. Acuity of the phenomenon explains the existence of multiple attempts of individual and collective for environmental protection. This study is concentrated in three regions of the island as shown in Figure 2.

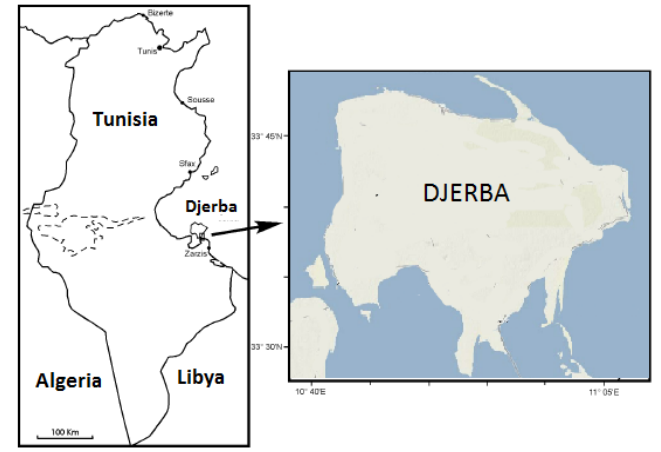

Figure 1. The island of Djerba

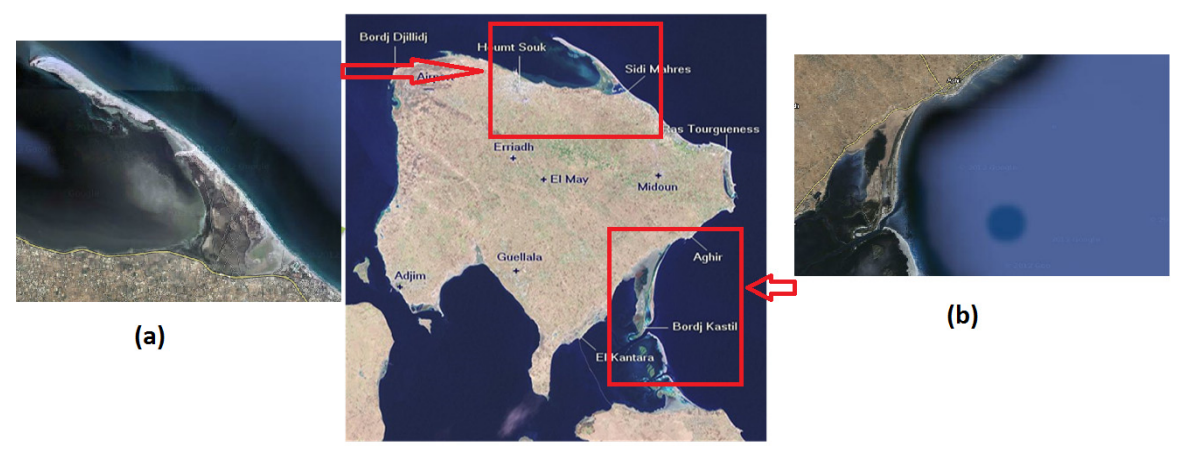

Figure 2. The study areas

The objective of this research is to rely on the existing long term data measurement to expect future short-term changes in Djerba. Twenty-five years measurement of changes will be determined based on remote sensing data and GIS.

Thematic Mapper remote sensing data have been used in various studies. Landsat TM images represents important record of remote sensing data with spatial scale of tens of meter spanning over 37 years, multi-spectral features and easy availability make them appropriate for monitoring land use change, and coastal changes (Sabyasachi \& Amit, 2011; Tucker, Grant, \& Dykstra, 2004; Ding, Wang, Wu, Zhou, Shi, \& Ding, 2007 ). 
To determine shoreline change on the Island of Djerba of Tunisia coastal zone, multi-spectral and multi-temporal satellite images were used in the present study. Each image was acquired in different dates: Landsat TM in 1984, Landsat TM in 1985, Landsat TM in 1986, Landsat TM in 1987, Landsat TM in 1992, Landsat TM in 2002, Landsat TM in 2006 and Landsat TM in 2009 (see Table 1).

Table 1. Used images

\begin{tabular}{ccc}
\hline Acquisition Date & Satellite Images & Resolution \\
\hline $1984 / 09 / 22$ & Landsat 5 TM & $30 \mathrm{~m}$ \\
$1985 / 01 / 28$ & Landsat 5 TM & $30 \mathrm{~m}$ \\
$1986 / 07 / 26$ & Landsat 5 TM & $30 \mathrm{~m}$ \\
$1987 / 08 / 14$ & Landsat 5 TM & $30 \mathrm{~m}$ \\
$1992 / 12 / 03$ & Landsat 5 TM & $30 \mathrm{~m}$ \\
$2002 / 05 / 19$ & Landsat 5 TM & $30 \mathrm{~m}$ \\
$2006 / 11 / 06$ & Landsat 5 TM & $30 \mathrm{~m}$ \\
$2009 / 06 / 23$ & Landsat 5 TM & $30 \mathrm{~m}$ \\
\hline
\end{tabular}

\section{Methodology}

We followed a three-step methodology to detect and measure changes in the shoreline (Figure 3). The first step was a preprocessing to extract automatically the study area from satellite images. Then, NDWI index from Landsat TM images were used after binarization to detect shorelines. The NDWI is defined as follows:

$$
\mathrm{NDWI}=(\text { Green-NIR }) /(\text { Green }+\mathrm{NIR})
$$

Landsat TM Green and NIR are respectively band 2 and band 4. This index is designed to (1) maximize reflectance of water using green wave- lengths, (2) minimize the low reflectance of NIR by water features and (3) take advantage of the high reflectance of NIR by vegetation and soil features. As a result, water features have positive values and enhanced, while vegetation and soil usually have zero or negative values and therefore are suppressed (Mcfeeters, 1996; Hanqiu, 2006).

The last step is the measurement of changes and the forecast of the future changes.

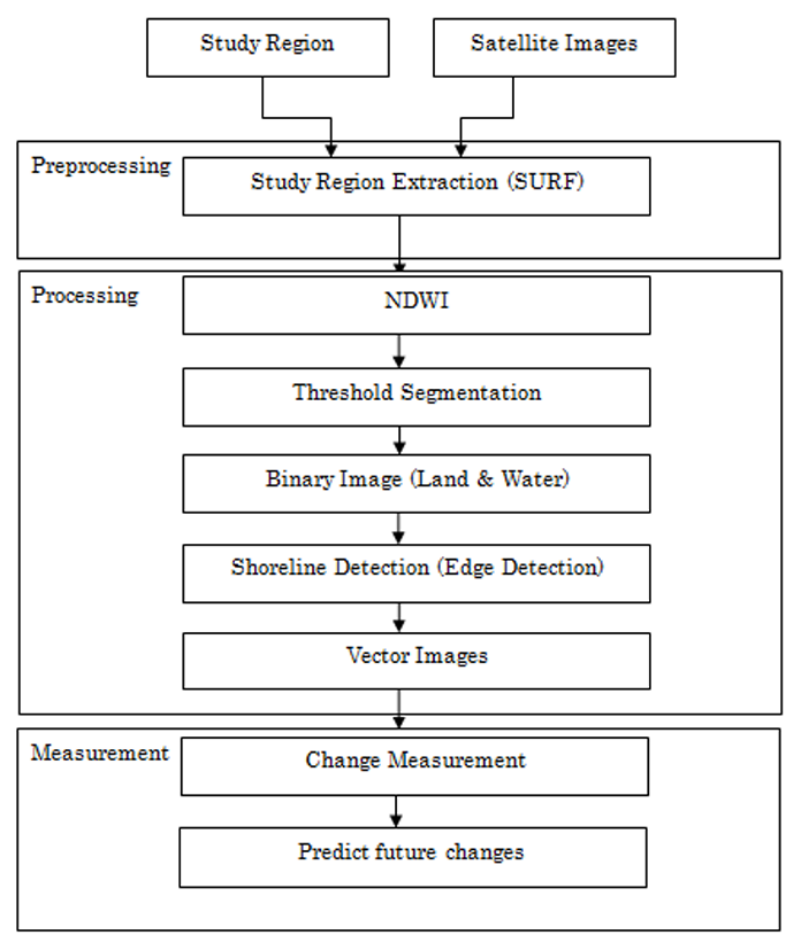

Figure 3. Methodology 


\subsection{Preprocessing}

The input to measure changes will be manually cropped image of the study area from the image acquired on 1984/06/18. This image will be used as reference image to extract the study area from the different images using the Speeded Up Robust Features (SURF) algorithm (Herbert, Andrea, Tinne, \& Luc, 2006). One of SURF's application is image registration. SURF uses a Haar wavelet approximation of the determinant of a Hessian blob detector. SURF is invariant against scale, translation and rotation, luminosity, and color. Then, the NDWI image will be computed for the extracted study region. Threshold segmentation (Otsu, 1979) was applied on the NDWI images to separate the land from the sea (Figure 4). The threshold calculated automatically to divide the image into two main segment water and land. This segmentation has improved the accuracy of the shoreline extraction as the value of the threshold presented by Otsu is set according to the local characteristics. To extract the shoreline from the segmented image, we applied the Canny edge detector (Canny, 1986). The Canny algorithm is adaptable to various environments. Its parameters allow it to be tailored to recognition of edges of differing characteristics depending on the particular requirements of a given implementation.

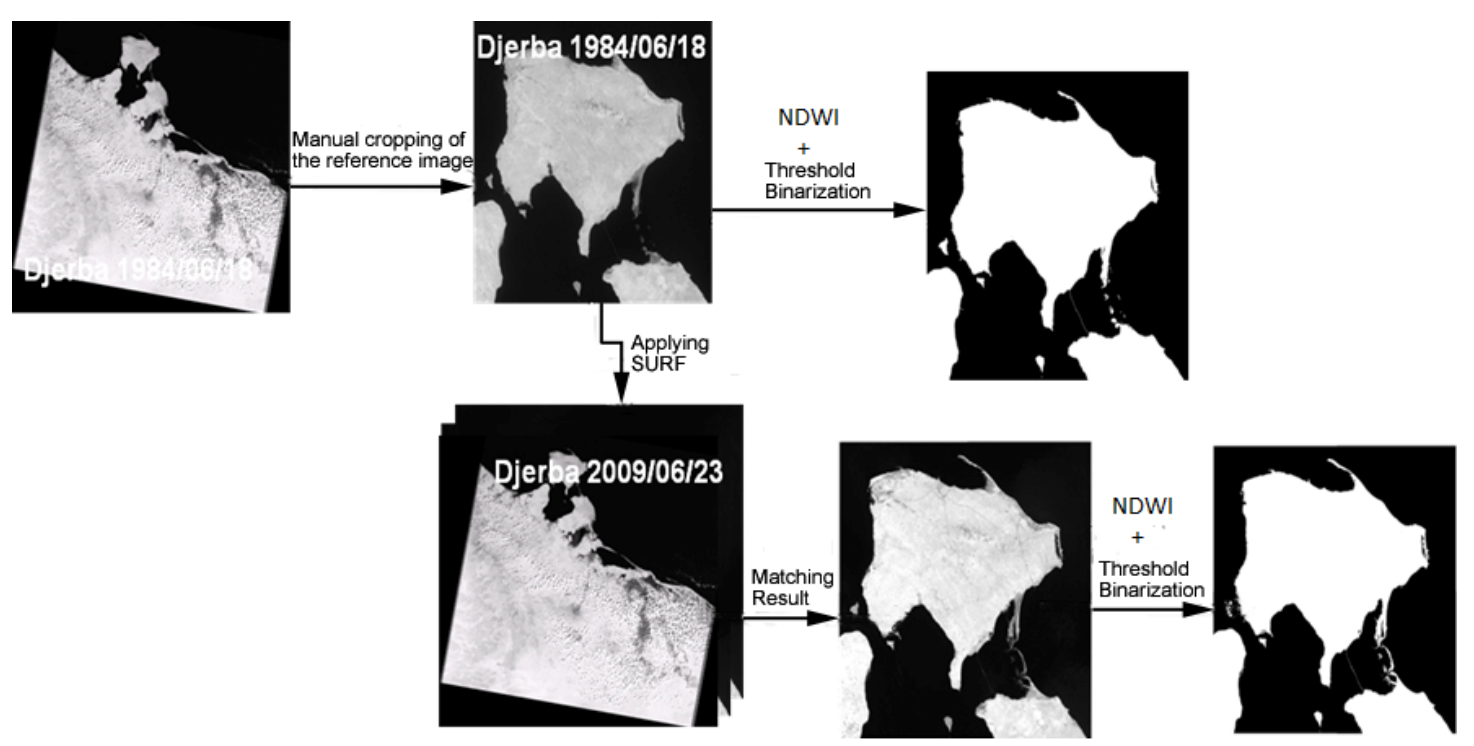

Figure 4. Preprocessing

Experiences have shown applying Canny edge detector in binarized images gives better results than using the NDWI image directly Figure 5. The result images are then converted into shape files for further processing and mapping in ArcGIS to measure the changes.

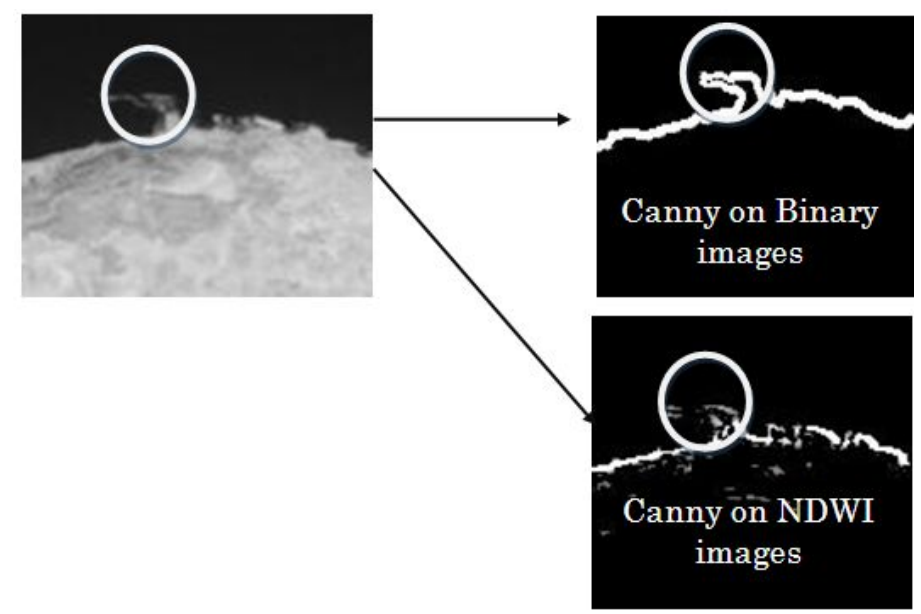

Figure 5. Coastline extraction 


\subsection{Change Measurement}

Two techniques were used to measure shoreline changes. The first technique measures changes using cell-to-cell comparison of the binary image. The second technique measures changes based on DSAS extension of ArcGIS.

Cell-to-cell comparison technique is used to calculate of new regions like the barrier island in our case. The binary images of the study area are divided into cells (Figure 6). Then, each selected image cell will be compared to the image cell in reference image and an image subtraction calculates the number of different land pixels to measure the changes.

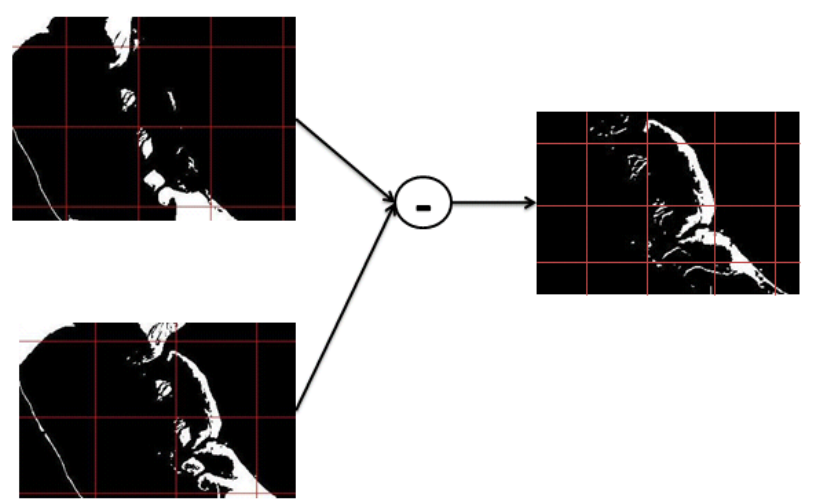

Figure 6. Bin-El ouidiane changes extraction

This technique has been used to measure the changes around the developed barrier islands near El-Kestil

The second technique calculates the rates of changes, such as erosion or accretion along shorelines based on the ArcGIS DSAS extension after the extraction of coastline from Landsat TM images. The DSAS is a computer software that computes the rate-of-change statistics from multiple historic shoreline positions residing in GIS (Thieler, Himmelstoss, Zichichi, \& Miller, 2005). DSAS generates transects that are cast perpendicular to the baseline at a user-specified spacing along-shore. The transect shoreline intersections along this baseline are then used to calculate the rate-of-change statistics. In this study we applied the system in three regions. Rass Errmall, El-Kestil and Aghir regions.

Based on the settings DSAS, 141 transects has been generated that are oriented perpendicular to the baseline at a $50 \mathrm{~m}$ spacing and about $8 \mathrm{~km}$ along Rass Errmall shore. For Aghir and El-Kestil Region (about $10 \mathrm{~km}$ alongshore) 191 transects were generated.

DSAS 4.2 has 6 statistical approaches to compute changes. In this study, End Point Rate (EPR) and Linear Regression Rate (LRR) approaches were used. LRR uses all the available data to compute long-term rate of changes. The EPR is calculated by dividing the distance of shoreline movement by the time elapsed between the oldest and the most recent shoreline. A LRR statistic can be determined by fitting a least-squares regression line to all shoreline points for a particular transect (Thieler, Himmelstoss, Zichichi, \& Miller, 2005). In this study uncertainty was $\pm 5 \mathrm{~m}$.

\section{Results and Discussion}

In this study, shoreline were extracted from satellite images for 1984, 1985, 1986, 1987, 1992, 2002, 2006 and 2009 by segmentation of the NDWI components with histogram based on automatic thresholding technique. The changes were calculated using cell-to-cell comparison around Bin Eloudiane regions. About $6000 \mathrm{~m}^{2}$ barrier islands have been developed around this region. The shoreline changes around Rass Errmal, Aghir and Elkestil were calculated using DSAS.

Aghir region (Figure 7.a-A) has been under erosion along the study period. The average of the erosion was around $-6.95 \mathrm{~m} / \mathrm{yr}$. In the other hand the region of Elkestil (Figure 7.a-B) was under an accretion of an average around $21.14 \mathrm{~m} / \mathrm{yr}$ during the study period. Rass Errmall area was divided into 2 segments according to the costal morphology. The average of erosion is around $-4.09 \mathrm{~m} / \mathrm{yr}$ (Figure7.b-A). Accretion trend is around +11.7 $\mathrm{m} / \mathrm{yr}$ for the same transects (Figure 7.b-B).

The results of this study present that shoreline changes such as erosion and accretion have caused the morphological changes at the coasts of Djerba Island. Maximum Accretion rate around Rass Ermall was around $29.9 \mathrm{~m} / \mathrm{yr}$ causing sedimentation of around $750 \mathrm{~m}$ from east to west. A maximum erosion rate around the same 
region was about $-54.37 \mathrm{~m} / \mathrm{yr}$. These statistics explain why this region in the island becomes longer and thinner.

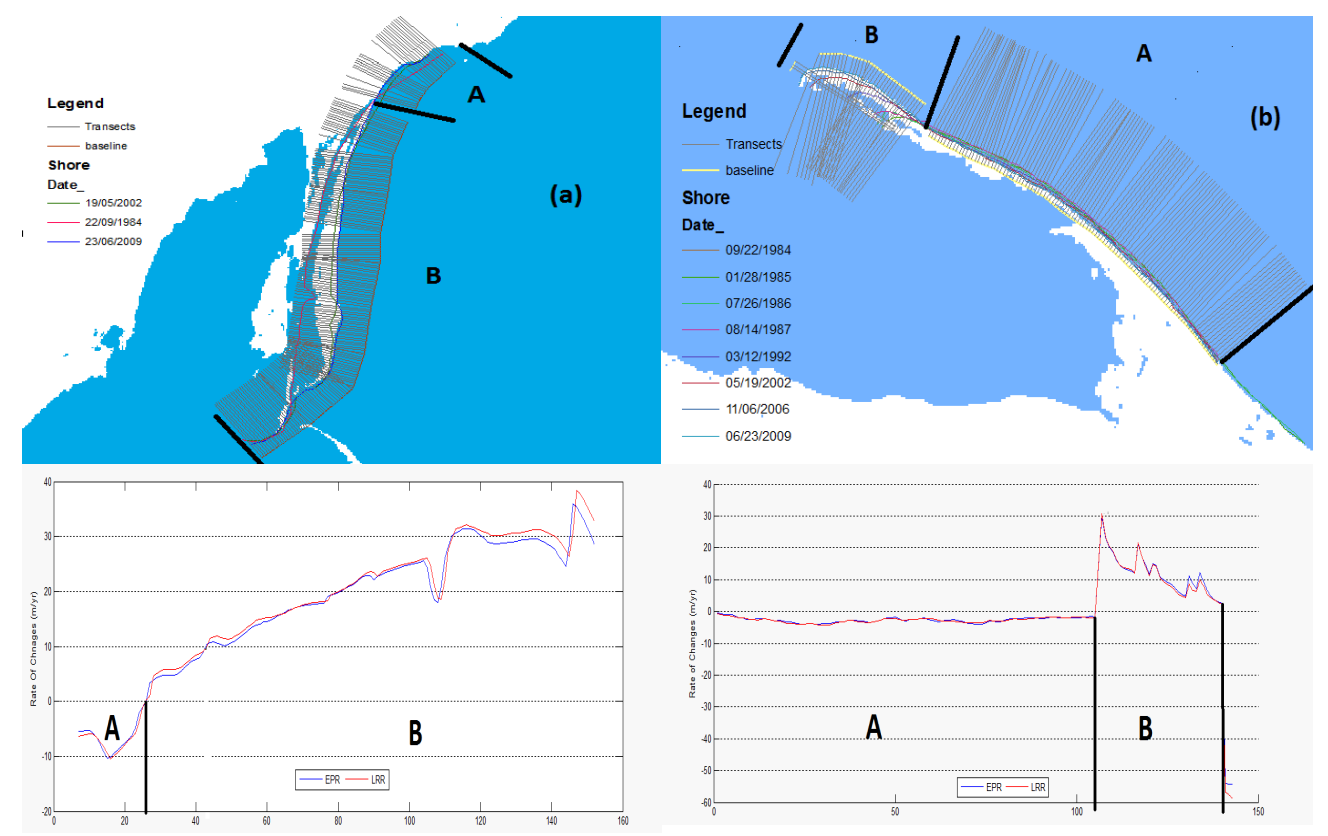

Figure 7. The resulted rates of coastline changes (erosion or accretion) estimated at each transect are plotted alongshore of the study area

Aghir area has been under a significant erosion with a maximum rate of change of $-10.43 \mathrm{~m} / \mathrm{yr}$. The lost area was about $4200 \mathrm{~m}^{2}$ between 1984 until 2009 from east to west. On the other hand remarkable coastal accretion was observed around Elkestil and a maximum rate of change was about $+38.36 \mathrm{~m} / \mathrm{yr}$. An area of around $81400 \mathrm{~m}^{2}$ during the study period was extended. In the Table 2, accretion and erosion around the study areas are listed. According to the finding from this study, decision makers should take into account the future of the coastal regions under investigation by making management plan to solve these problems. In fact the coastal changes are the causes of the construction around the shore and the use of the dunes around Aghir caused the erosion of this area. Also, the changes around the Rass Errmall are in relationships with the touristic activities in this area. The municipalities of the regions should be organized to monitor these regions and control the constructions around these regions.

Table 2. Rates of change

\begin{tabular}{llll}
\hline Region & A & B & Mean \\
\hline Rass Errmall & & & \\
Erosion Trend (m/yr) & -4.09 & - & -4.09 \\
Accretion Trend (m/yr) & - & 11.07 & 11.07 \\
Number of transects (141) & 34 & 107 & - \\
Transect Length (m) & 1700 & 1700 & - \\
Baseline length (m) & 1876 & 5248 & - \\
\hline Region & A & B & Mean \\
\hline Aghir (A) \& El Kestill (B) & & & \\
Erosion Trend (m/yr) & -6.95 & - & -6.95 \\
Accretion Trend (m/yr) & - & 21.14 & 21.14 \\
Number of transects (191) & 26 & 195 & - \\
Transect Length (m) & 1500 & 1500 & - \\
Baseline length (m) & 1257 & 8214 & - \\
\hline
\end{tabular}




\section{Conclusion}

This work has focused on the development of a method for automatic measurement of shoreline changes of an island using Landsat data. The method is based on two techniques to detect the changes. Three areas of the study region were under monitoring. In general, accretion are more significant in the most part study areas. However, erosion has been remarkable around the area of Aghir and also in the north part of Rass Ermall area. This study raises an alert to the decision maker in the different municipalities of the island to avoid illegal activities in the coastal zones. It is also important to keep monitor the changes around the island and take in consideration these changes on the future urban planning of the island. An online system will be developed in the goal to have a continuous monitoring.

\section{Acknowledgements}

The work was supported by the MEXT Japanese Government scholarship.

\section{References}

Ali, T., \& Li, R. (2000). Spatio-temporal modeling of oil erosion and contaminated sediment transport in Lake Erie coastal area. ASPRS Annual Conference, Washington, D.C., May 22-26, 2000 (CD-ROM).

Bouchahma, M., Wanglin, Y., \& Oeussar, M. (2012). Island coastline change detection based on image processing and remote sensing. Computer \& Information Science, 5(3), 27-36.

Canny, J. A. (1986). Computational approach to edge detection. IEEE Trans. Pattern Analysis and Machine Intelligence, 8(6), 679-698. http://dx.doi.org/10.1109/TPAMI.1986.4767851

Ding, H., Wang, R. C., Wu, J. P., Zhou, B., Shi, Z., \& Ding, L. X. (2007). Quantifying land use change in Zhejiang coastal region, China using multi-temporal Landsat TM/ETM+ images. Pedosphere, 17(6), 712-720. http://dx.doi.org/10.1016/S1002-0160(07)60086-1

Ghanavati, E., Firouzabadi, P. Z., Jangi, A. A., \& Khosravi, S. (2008). Monitoring geomorphologic changes using Landsat TM and ETM+ data in the Hendijan River delta, southwest Iran. International Journal of Remote Sensing, 29(4), 945-959. http://dx.doi.org/10.1080/01431160701294679

Hanqiu, X. (2006). Modification of normalised difference water index (NDWI) to enhance open water features in remotely sensed imagery. International Journal of Remote Sensing, 27(14), 3025-3033. http://dx.doi.org/10.1080/01431160600589179

Herbert, B., Andreas, E., Tinne, T., \& Luc, V. G. (2008). SURF: Speeded Up Robust Features. Computer Vision and Image Understanding (CVIU), 110(3), 346-359. http://dx.doi.org/10.1016/j.cviu.2007.09.014

Kuleli, T., Guneroglu, A., Karsli, F., \& Dihkan, M. (2011). Automatic detection of shoreline change on coastal Ramsar wetlands of Turkey. Ocean Engineering, 38(10), 1141-1149. http://dx.doi.org/10.1016/j.oceaneng.2011.05.006

Li, R., Di, K., \& Ma, R. (2001). A comparative study of shoreline mapping techniques. In: Proceedings of the Fourth International Symposium on Computer Mapping and GIS for Coastal Zone Management, Halifax, Nova Scotia, Canada.

Li, R., Liu, J. K., \& Felus, Y. (2001a). Spatial modeling and analysis for shoreline change detection and coastal erosion monitoring. Journal of Marine Geodesy, 24(1), 1-12. http://dx.doi.org/10.1080/01490410151079891

Li, R., Ma, R., Di, K., \& Ali, T. (2001b). Coastline mapping and change detection using one-meter resolution satellite imagery. A project report, department of civil and environmental engineering and geodetic science, the ohio state university.

Maiti, S., \& Bhattacharya, A. K. (2009). Shoreline change analysis and its application to prediction: a remote sensing and statistics based approach. Marine Geology, 257(1-4), 11-23. http://dx.doi.org/10.1016/j.margeo.2008.10.006

Mcfeeters, S. K. (1996). The use of normalized difference water index (NDWI) in the delineation of open water features. International Journal of Remote Sensing, 17(7), 1425-1432. http://dx.doi.org/10.1080/01431169608948714

Mills, J. P., Buckley, S. J., Mitchell, H. L., Clarke, P. J., \& Edwards, J. (2005). A geomatics data integration technique for coastal change monitoring. Earth Surface Processes and Landforms, 30(6), 651-664. http://dx.doi.org/10.1002/esp.1165 
Otsu, N. (1979). A threshold selection method from gray level histograms. IEEE Transactions on Systems, Man and Cybernetics, 9(1), 62-66. http://dx.doi.org/10.1109/TSMC.1979.4310076

Rasuly, A., Naghdifar, R., \& Rasoli, M. (2010). Monitoring of Caspian sea coastline changes using object-oriented techniques. Procedia Environmental Sciences, 2, 416-426. http://dx.doi.org/10.1016/j.proenv.2010.10.046

Rebelo, L. M., Finlayson, C. M., \& Nagabhatla, N. (2009). Remote sensing and GIS for wetland inventory, mapping and change analysis. Journal of Environmental Management, 90, 2144-2153. http://dx.doi.org/10.1016/j.jenvman.2007.06.027

Sabyasachi, M., \& Amit, K. B. (2011). A three-unit-based approach in coastal-change studies using Landsat images. International Journal of Remote Sensing, 32(1), 209-229. http://dx.doi.org/10.1080/01431160903439965

Thieler, E. R., Himmelstoss, E. A., Zichichi, J. L., \& Miller, T. L. (2005). Digital Shoreline Analysis System (DSAS) version 3.0: an ArcGIS extension for calculating shoreline change. US Geological Survey Open-File Report 2005-1304

Tucker, J. C., Grant, D. M., \& Dykstra, J. D. (2004). NASA's global ortho-rectified Landsat data set. Photogrammetric Engineering and Remote Sensing, 70(3), 313-322.

U.S. Army Corps. of Engineers. (1992). Engineering and Design - Coastal Littoral Transport. Publicly released publication no. EM 1110-2-1502, Washington D.C. 